\title{
Corrosion resistance of the welded junction of aluminum alloy of the Al-Mg-Si-Cu system
}

\author{
L. I. Nyrkova ${ }^{1} \bullet$ S. O. Osadchuk ${ }^{1} \bullet$ T. M. Labur ${ }^{1} \bullet$ Yu. V. Borisenko ${ }^{2}$
}

Received: 16 September 2020 / Accepted: 24 November 2020

\begin{abstract}
The paper deals with the hybrid action tool for cleaning of cavities and elements of turbine units whose operation is based on a combination of action of a water-ice flow with mechanical shock influence of the small concentrated masses mounted on elastic suspensions. Receiving energy from the flow, the masses, performing self-oscillating motion, come into contact with the treated surface having a layer of strong contamination, and create a multipoint shock-cyclic loading of the surface, which results in active development of initial defects of the contamination film, due to which the following action of the water-ice stream produces better and more productive cleaning. It is shown that the generated local stresses, determined on the basis of Hertz contact problems, reach 15-20 MPa, do not have a significant effect on the surface of the base, which is a thin curves shell, do not change the state of its surface in the plane of adhesion, but result in defects in surface film in the form of cracks and delaminations. In this case the film is eliminated by waterice flow more dynamically. The use of water-ice jet, formed by the original tubeless device, enables the formation of a wide flow (with the top angle of $\pi / 12 \ldots \pi / 6)$ and the work of its ice particles is spent on grinding the surface film. The jet stream cleans the surface and removes the products of destruction beyond the impact.

The use of a hybrid tool has increased the productivity of treatment with the wetting angles of the jet flow, different from $\pi / 2$, by more than $30 \%$, while the consumption of cryogenic liquid (liquid nitrogen) is reduced by $20-25 \%$.

The process modeling is performed, the conditions of the destruction of the adhesive bond of the contaminant film with the surface are estimated, the conditions of its rational execution are determined.
\end{abstract}

Keywords: hybrid tool, water-ice flow, surface cleaning, modeling, surface mud films.

\section{Introduction}

The Al-Mg-Si system alloys are deformable thermally hardening aluminum alloys, widely used in the aircraft industry, rocket construction, shipbuilding, rail and road transport. The main alloying elements in these alloys are $\mathrm{Mg}$ and $\mathrm{Si}$. In order to improve their various properties, they are alloyed additionally with $\mathrm{Cu}, \mathrm{Mn}, \mathrm{Cr}, \mathrm{Zn}$ and $\mathrm{Ti}$. Properties of thermally hardened aluminum alloys strongly depend on the cooling rate of the product during quenching, which determines the structure and level of residual stresses. The reduction of structural strength, the tendency

\section{I. Nyrkova}

lnyrkova@gmail.com

1 E.O. Paton Electric Welding Institute of the National Academy of Sciences of Ukraine, Kyiv, Ukraine

2 National University of Technologies and Design, Kyiv, Ukraine to pitting and intergranular corrosion with slow cooling from the quenching temperature is associated with the formation of large unequiaxial separations, free-separation zones, and a decrease in the fraction of inclusions of the strengthening phase.

Interest in alloys of the $\mathrm{Al}-\mathrm{Mg}-\mathrm{Si}-(\mathrm{Cu})$ system is due to the fact that they have a good complex of strength and corrosion properties, high technological ductility and weldability [1].

Their strengthening is mainly due to the formation of magnesium and silicon containing separations during aging [2-4]. A large number of papers are devoted to the effect of heat treatment on the properties of Al-Mg-Si-Cu alloys including corrosion resistance.

For example, there are data [5] that copper is added into $\mathrm{Al}-0,3 \% \mathrm{Mg}-0,5 \% \mathrm{Si}$ alloys for additional hardening in the course of artificial aging at $180^{\circ} \mathrm{C}$ in small quantities $(0.5-0.8 \%)$. However, the addition of copper into an alloy that is long-lasting ( $4300 \mathrm{hrs)}$ ) at $90{ }^{\circ} \mathrm{C}$ (for example, in car radiators) is not practical, since both alloys have a similar 
level of tensile strength. It has been experimentally proved that the effect of the copper additive on the formation of the $\beta$-phase at 90 and $180{ }^{\circ} \mathrm{C}$ is different.

Most alloys of the Al-Mg-Si-Cu system have an increased quench sensitivity that affects their mechanical and corrosion properties, as shown in the paper [6]. The main factor ensuring the strength of alloys is the density of the dispersoids, which is determined by the temperature and the duration of heating during homogenization. When quenching with a decrease in the cooling rate, the dispersoids become centers of the nucleation of coarse non-stabilizing $\mathrm{Mg}-\mathrm{Si}$-particles, and zones free from the separations of the strengthening phases appear. This leads to a decrease in the concentration of $\mathrm{Mg}$ and $\mathrm{Si}$ in the solid solution and, as a consequence, to a lower level of strength and hardness of the alloy.

As a result of studies carried out by the author of the paper [7], it has been established that crystals of the $\beta$ '-phase formed during slow cooling mainly on the dispersoid, being an anode phase, dissolve in the process of corrosion, resulting in the appearance of structural pitting. By the potentiodynamic method and the method of electrochemical impedance spectroscopy, it has been shown that the dependence of the corrosion rate on the duration of exposure during isothermal quenching has an extreme character. Based on the fundamental equations of the theory of corrosion, crystallization and diffusion mass transfer, a scientifically based mathematical model that makes it possible to predict the effect of cooling modes on the corrosion rate of dispersion-hardening alloys has been proposed.

Research of the effect of separations received at the natural aging (T4), overaging (OA) and strong over-aging (SOA) of the Al-Mg-Si-Cu system alloy 6111 on the processes of returning and recrystallization that proceeded after cold rolling during the annealing at 325 and $445{ }^{\circ} \mathrm{C}$ has shown that after the annealing, the fraction of recrystallization and hardening for the state $\mathrm{T}$ and $\mathrm{OA}$ was $0.3-0.5$. For the state of SOA, almost completely recrystallized structure and a maximum softening have been obtained, which is due to the process of returning, the agglomeration of the particles of emissions, the presence of separationfree zones and the duration of annealing [8].

It has been noted in the paper [9] that alloys of the $\mathrm{Al}-\mathrm{Mg}-\mathrm{Si}-\mathrm{Cu}$ system are corrosion-resistant, but the separations of the second phases $[\beta \quad(\mathrm{Mg} 2 \mathrm{Si})$ and $\mathrm{Q}$ (All4Si7Mg8Cu2)] can promote the intergranular corrosion. Investigations of the kinetics of the intergranular and pitting corrosion of 6111 alloy in the underaged, aged by maximum strength and overaged states have shown that the degree of corrosion damage increases with an increase in strengthening. The phases along the grain boundaries with a high copper content behave as cathodes and create microgalvanic pairs with the adjacent zones with a lowered $\mathrm{Cu}$ and Si content, which can lead to an intensification of intergranular fracture. At the stage of overaging, the tendency of the alloy to the intergranular corrosion, as well as the degree of strengthening, decrease.
The effectiveness of the application of low-temperature thermomechanical treatment and multistage aging of the alloy 1370 of the Al-Mg-Si-Cu system for reducing the susceptibility to the intergranular corrosion and increasing of strength properties has been demonstrated in the paper [10]. As a result of deformation by cold rolling or stretching between strengthening and three-stage aging of sheets with the thickness of $12-20 \mathrm{~mm}$, the depth of the intergranular corrosion (IGC) does not exceed $0.1 \mathrm{~mm}$, and the temporary resistance to rupture reaches the level of $\sigma_{\mathrm{B}}=425-440 \mathrm{MPa}$. The application of multistage aging T78 for the alloy 6056, similar in composition, results in a decreasing in the strength of up to $365 \mathrm{MPa}$ while eliminating the tendency to the intergranular corrosion and to a depth of pitting corrosion up to $0.16 \mathrm{~mm}$.

A noticeable increasing in strength characteristics while retaining relative elongation at a sufficiently high level of sheets of the Al-Mg-Si system alloy is also achieved during auto-frettage with $\varepsilon=10-40 \%$ degree, which corresponds to degrees of deformation in different areas of the part obtained by cold stamping. The heating of the sheets at the temperature of $190{ }^{\circ} \mathrm{C}$ for 30 minutes after auto-frettage has little influence on the strength characteristics, slightly increasing the relative elongation, which may indicate a relaxation of stresses in the parts obtained by cold stamping. Sheets of the Al-Mg-Si-Cu alloy by their specific strength and corrosion resistance significantly outperform sheets of steel used in the automotive industry and can be used effectively instead of steel sheets in car designs [11].

The method for prediction of corrosion losses of deformable aluminum alloys for long periods of exposure, based on the analysis of the kinetics of changes in the parameters of corrosion attack in the case of naturally accelerated tests, is of interest [12]. In the calculations of the integral coefficient of corrosion attack for structural elements, the results of the assessment of corrosion damage detected by non-destructive control methods are used: by means of visual assessment, laser scanning microscopy, corrosion resistance analysis of control samples after naturally accelerated or laboratory tests, according to which the tendency of the alloy to the IGC is established. Conducting complex investigations of corrosion resistance of materials in conditions of aggressive influence of the environment will allow to evaluate the behavior of materials in the most severe conditions of operation in terms of the influence of external factors [13].

As it follows from the review of the results of modern studies concerning the stability of alloys of the Al-Mg$\mathrm{Si}-\mathrm{Cu}$ system, they are all primarily devoted to the base metal, and there are not enough papers about the resistance of welds. Therefore, the work, the results of which are presented below, represents a scientific and practical interest. The purpose of the work was to study the corrosion resistance of welded junctions of the of aluminum alloy of the Al-Mg-Si-Cu doping system obtained by a non-melting electrode in various conditions. 


\section{Materials and test techniques}

The object of the research was a welded junction of aluminum alloy of the $\mathrm{Al}-\mathrm{Mg}-\mathrm{Cu}-\mathrm{Si}$ doping system, obtained by a nonfusing arc-welding electrode.

Electrochemical investigations were carried out using potentiometry and polarization curves methods by Potentiostat PI-50-1.1 and Programmer Pr-8. The polarization curves were measured on the base metal and a weld using a clamping cell. Chlorine-silver electrode was chosen as a reference electrode, platinum - as an auxiliary one.

Before testing for resistance to intercrystalline and exfoliation corrosion, the specimen were treated in a solution of $100 \mathrm{~g} / \mathrm{dm}^{3}$ of sodium hydroxide at the temperature of $(50 \pm 5){ }^{\circ} \mathrm{C}$ during $30 \mathrm{~min}$. Before immersion in the test solution, the specimen were wiped off with a cotton swab moistened with ethyl alcohol.

Tests and estimation of resistance against intergranilar corrosion were performed by the standard method in accordance with GOST 9.021 [14] in solution of a such composition: $30 \mathrm{~g} / 1$ sodium chloride and $10 \mathrm{ml} / 1$ hydrochloric acid with the density $1.19 \mathrm{~g} / \mathrm{cm}^{3}$ ).

Test duration was 24 hours.

Tests and estimation against exfoliation corrosion were performed in accordance with GOST 9.904 [15] in the solution in solution of a such composition: $20 \mathrm{~g} / \mathrm{dm}^{3}$ of potassium bichromate and $13.4 \mathrm{~g} / \mathrm{dm}^{3}$ of hydrochloric acid.

The duration of the test was 7 days. The ratio of the volume of solution to the unit of surface area of the specimen was $10 \mathrm{~cm}^{3} / 1 \mathrm{~cm}^{2}$.

Corrosion cracking resistance tests were carried out under a constant stress of $160 \mathrm{MPa}$ on Signal machine in accordance with GOST 9.019 [16], with the full immersion into $3 \% \mathrm{NaCl}$ solution. Specimens of the base metal and welded joints of $110 \times 10 \times 1.2 \mathrm{~mm}$ in size were used. The sketch of the testing specimen is shown in Fig. 1. In the specimens of the welded joint, the weld is arranged in the middle of the specimen perpendicular to the stretching stress. Edges of samles were polished with abrasive paper of different grain size. Preparation of the surface of the specimen was performed in accordance with GOST 9.913 (Section 3) [17]. The duration of the test was 45 days.

Metallographic studies were conducted according to the standard techniques.
All the tests were carried out at the temperature of $(20 \pm 2)^{\circ} \mathrm{C}$ and relative humidity of $760 \mathrm{~mm} \mathrm{Hg}$.

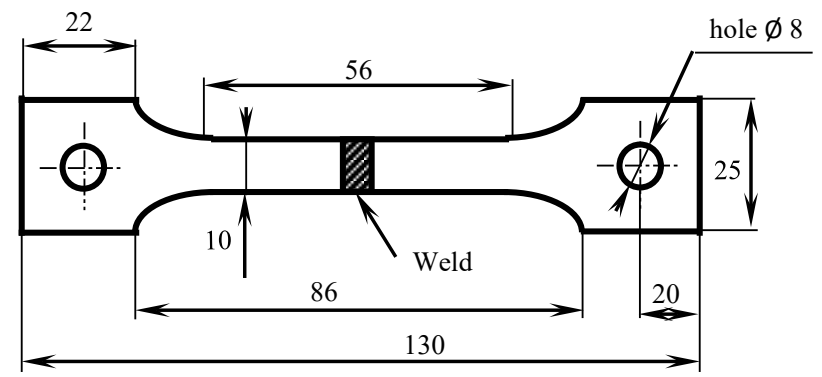

Fig. 1. Sketch of the specimen for testing under constant load conditions

\section{Results and discussion}

\section{Chemical composition, mechanical properties and structure}

For the manufacture of welded joints, sheets of aluminum alloy with the thickness of $1.2 \mathrm{~mm}$ longitudinally rolled were used. Chemical composition of the alloy is (wt.\%):

(0.45-0.9) Mg, (0.5-1.2) Si, ( 0.15-0.35) Mn, (0.1-0.5) Cu, $(0.05-0.1) \mathrm{Ca}, 0.25 \mathrm{Cr}, 0.2 \mathrm{Zn}, 0.15 \mathrm{Ti}, 0.5 \mathrm{Fe}$, other elements - no more than 0.1 .

The development of welding technology and the choice of optimal mode was not the subject of this work. We would like to note only that the free arc welding was carried out with a different polar current of a sinusoidal wave using the inverter MW2000 of Fronius Company. Wires of Sv 1217 grade with the diameter of $2.0 \mathrm{~mm}$ was used. Welding process was carried out in a protective gas argon (in accordance with GOST 10157 [18]). Under these conditions, a tight weld without defects was formed. After welding, the tendency of the welds to form hot cracks was estimated using Holdcraft's samples [19].

The mechanical properties of the base metal and welded joints are shown in Table. 1.

Table 1. Mechanical properties of the base metal of aluminum alloy Al-Mg-Cu-Si and its welded joints made by hand arc welding with a nonfusing electrode using filler wires of Sv 1217 grade

\begin{tabular}{|c|c|c|c|c|c|c|}
\hline Material & $\sigma_{\mathrm{B}}, \mathrm{MPa}$ & $\sigma_{0,2}, \mathrm{MPa}$ & $\delta, \%$ & $\alpha, \operatorname{grad}$ & $K_{B}=\sigma_{B} / \sigma_{B w j}$ & $A, \%$ \\
\hline Base metal (longitudinal direction) & 250.5 & 187.7 & 18.9 & 180 & - & $65.8-85.5$ \\
\hline Welded junction & 208.7 & 147.5 & 5.1 & 45 & $0.83-0.86$ & 38.5 \\
\hline
\end{tabular}

Key: $\sigma_{B}-$ ultimate strength; $\sigma_{0,2}$ - yield strength; $\sigma_{B w j}-$ ultimate strength of the weld; $\delta$ - relative contraction; $\alpha$ - bending angle; $A$ - the relative length of a hot crack 
According to the results of mechanical tests, it has been established that the specimens of welded joins are breaking in the HAZ at the distance of 3-5 mm from the fusion boundary, which is associated with the metal weakening under the influence of technological heating.

Metallographic analysis of the macrostructure of the welded junctions of aluminium alloy of $\mathrm{Al}-\mathrm{Mg}$-Si-Cu system in different zones: in the weld, in the zone of its fusion with the main metal and in the HAZ (Fig. 2), has shown that the structure of the weld is homogeneous, has a finedendritic structure, without rough defects.

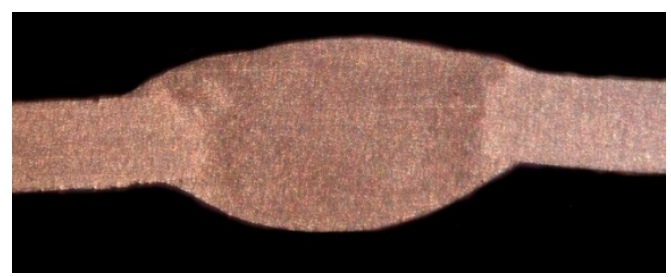

Fig. 2. Macrostructure of the welded joint specimen, $\times 13$

Studies of metallographic samples (in the untreated condition) have established the absence of rough defects. Scattered pores size of which is not more than $0.08 \mathrm{~mm}$ were detected on the face surface of the weld after removal of technological enhancement. The total length of the chain of small pores was near $7-8 \mathrm{~mm}$ at the weld length near $100 \mathrm{~mm}$, the distance between them was near (11.0 15.0) $\mathrm{mm}$. This is twice low than the values valid by the DSTU EN ISO 10042 [20]. Such porosity in the center of the welds is typical to the welded junctions obtained using the free arc and is not dangerous, since their sizes do not exceed the normalized values.

In the near-weld zone, three areas of a varying degree of etching can be observed, which reflect the effect of the thermal cycle of welding on the metal structure, Fig. 3.

As a result of influence of thermal cycle of welding, the decomposition of the supersaturated solid solution, accompanied by the separation and coagulation of inclusions of insoluble phases, as well as the dissolution of the previously formed strengthening phases, Fig. 3b, occurs. A characteristic feature of these processes is the instability of de- cay within a single grain. The boundary areas are thus enriched with alloying elements, and the volume is depleted. Thin eutectic layers are formed along the boundaries of crystallites. A significant number of the base alloying elements and impurities cause the formation of a large number of metastable phases during crystallization, which are arranged evenly along the intersection of the welds but vary in size and shape. In the welds, Fig. $3 a$, the intercrystal layers are more rough and have clear outlines.

\section{Electrochemical properties}

Research of the influence of the thermal cycle of welding on the electrochemical heterogeneity of the weld was carried out by the potentiometry method. The potential corrosion distribution was measured and analyzed on the specimen surface of the welded junction.

Fig. 4 shows the corrosion potentials of different zones of welded junction of the of aluminum alloy of the $\mathrm{Al}-\mathrm{Mg}-\mathrm{Si}-\mathrm{Cu}$ doping system. It has been established that the weld and HAZ potentials have more noble values in comparison with the base metal: the potential difference between the base metal and the weld is about $95 \mathrm{mV}$, between the base metal and the HAZ is about (16-25) $\mathrm{mV}$. According to GOST 9.005 (item 4.4.5) [21], the potential difference in welded structures should not exceed (30-50) $\mathrm{mV}$. That is, it is thermodynamically likely that at the contact with a corrosive-aggressive medium, the base metal will predominantly break down. The potential difference between the base metal and the HAZ is permissible. Taking into account the larger area of the base metal in the construction compared to the weld (the weld area does not exceed $10 \%$ of the area of the base metal), you can expect a satisfactory resistance of the welded junction against uniform corrosion. But it must be keep in mind that the resistance of the weld to local corrosion, and under conditions of a joint effect of corrosive medium and stresses may vary.

The polarization properties of welded junction of aluminum alloy of $\mathrm{Al}-\mathrm{Mg}-\mathrm{Si}-\mathrm{Cu}$ dopping system in $3 \%$ $\mathrm{NaCl}$, presented in Fig. 5, have been studied. In the neutral medium, corrosion of the base metal will occur with diffusion control. From the analysis of the anode polarization curves it can be seen that the length of the area of the active
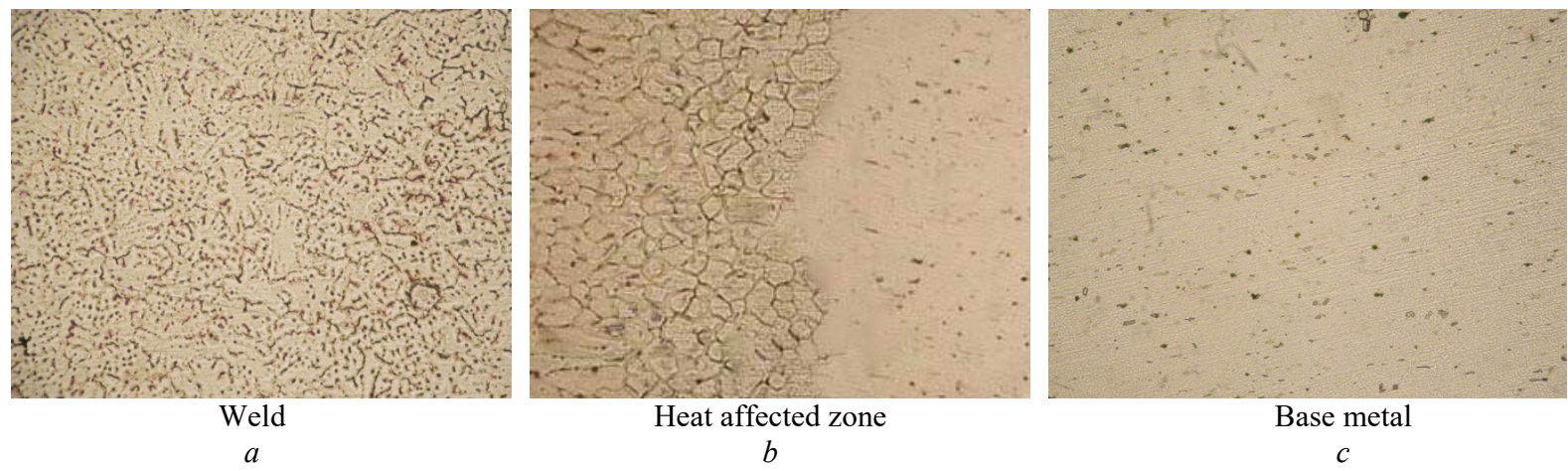

Fig. 3. Microstructure of different zones of the weld of aluminum alloy of the Al-Mg-Cu-Si system, $\times 320$ 


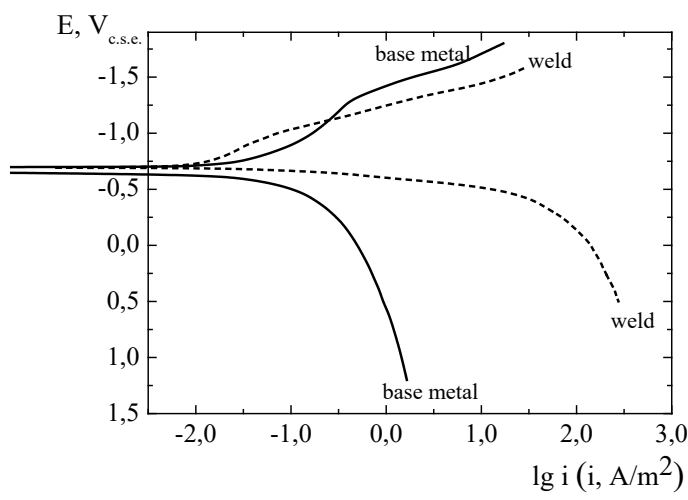

Fig. 4. Corrosion potentials' distribution on the surface of the welded junction of aluminum alloy $\mathrm{Al}-\mathrm{Mg}-\mathrm{Cu}-\mathrm{Si}$ in $3 \% \mathrm{NaCl}$ solution

anodic dissolution for the metal weld is about $0.16 \mathrm{~V}$, of the base metal - is about $0.10 \mathrm{~V}$. Anodic dissolution currents in the active zone of the base metal are substantially less than anodic currents dissolution of the weld and are equal to, for example, at the potential $-0.5 \mathrm{~V}-0.107$ and $14 \mathrm{~A} / \mathrm{m}^{2}$, respectively.

The limit diffusion current of oxygen determined from the cathodic polarization curves is larger on the base metal in comparison with the weld: $0.2 \mathrm{~A} / \mathrm{m} 2$ and $0.03 \mathrm{~A} / \mathrm{m} 2$, respectively. The potential of hydrogen reduction on the weld is less negative in comparison with the base metal, -0.98 and -1.3 , respectively, indicating that the process of hydrogen reduction on the weld is facilitated in the corrosive medium.

Thus, the thermal cycle of welding leads to the formation of electrochemical heterogeneity between the weld and the base metal, which, depending on the aggressiveness of the corrosive medium in the operating conditions, is likely to create conditions for the predominant breaking down of the weld and the near-weld zone.

\section{Resistance against various types of corrosion}

The IGC resistance tests have shown, Fig. 6, $a$, that the depth of destruction of the grain boundaries of the base metal is from 0.082 to $0.086 \mathrm{~mm}$, and the weld $-(0.245$ $-0.350) \mathrm{mm}$. An increasing of the depth of destruction of the grain boundaries in the welded junction indicates the weakening of the near-weld zone during welding.

Fig. 7 shows the appearance of the surface of the base metal and welded junctions after the exfoliation corrosion resistance tests.

According to the results of the conducted research, it has been found that exfoliations of the base metal, the diameter of which does not exceed $1 \mathrm{~mm}$, and the size of the area of such exfoliations is not more than $1.5 \%$, have been noticed. Exfoliations on the side surfaces were not detected.

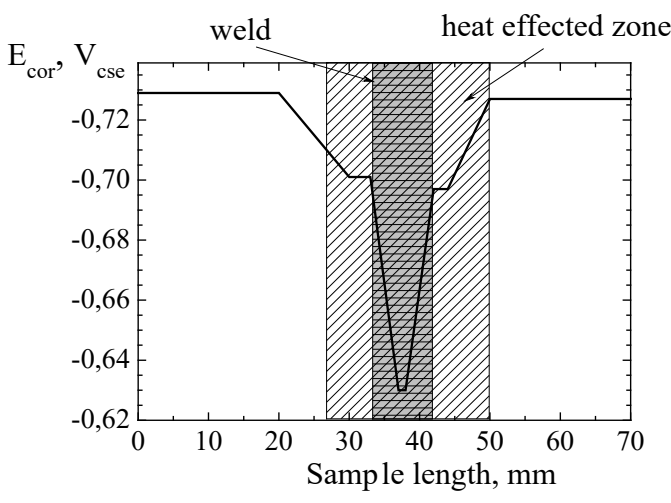

Fig. 5. Polarization curves on the base metal and the weld of aluminum alloy $\mathrm{Al}-\mathrm{Mg}-\mathrm{Cu}-\mathrm{Si}$ in $3 \% \mathrm{NaCl}$ solution

On the specimens of welded junctions, attention was drawn to the weld and the near-weld zone. According to the results of the examination, it has been established that changes in the heat-affected zone and on the weld were not detected. Exfoliations on the working surface and on the side surfaces of the heat-affected zone were also absent.

According to the results of the visual examination according to GOST 9.904 [15], exfoliation corrosion resistance of the base metal of aluminium alloy of Al-Mg-Si-Cu doping system was estimated by $2-3$ ball on the 10 -point scale, the of welded junction and the heat-affected zone - by 1 ball.

Thus, the welding process does not worsen the exfoliation corrosion resistance of the welded junction compared to the base metal.

The results of the study of the base metal of aluminium alloy of $\mathrm{Al}-\mathrm{Mg}-\mathrm{Si}-\mathrm{Cu}$ doping system resistance against corrosion cracking have shown that no damages occurred within 45 days. Therefore, the research was continued until the breaking down of the specimens. It has been found that the time of speccimens' destruction was from 67 to 88 hours, but the destruction of all the specimens occurred outside the working part (in the plane of the gripping part). As an example, Fig. 8a shows the appearance of a specimen of the base metal, which collapsed after 74 hours of corrosion-mechanical tests. Darkening of the surface of the specimens and the formation of a large number of pittings were observed. Considering the fact that breaking of specimens occurred outside the working part, it can been assumed that the presence of pittings does not aggravate the mechanical properties of the base metal.

As for the welded junction of aluminium alloy of Al$\mathrm{Mg}-\mathrm{Si}-\mathrm{Cu}$ doping system, a significant reduction of the fracture time compared to the base metal was observed. So, the destruction time of specimens of welded junctions ranged from 1 to 49 hours. A large data discrepancy indicates the heterogeneity of the weld, probably due to the weakening of the near-weld zone under the influence of the 

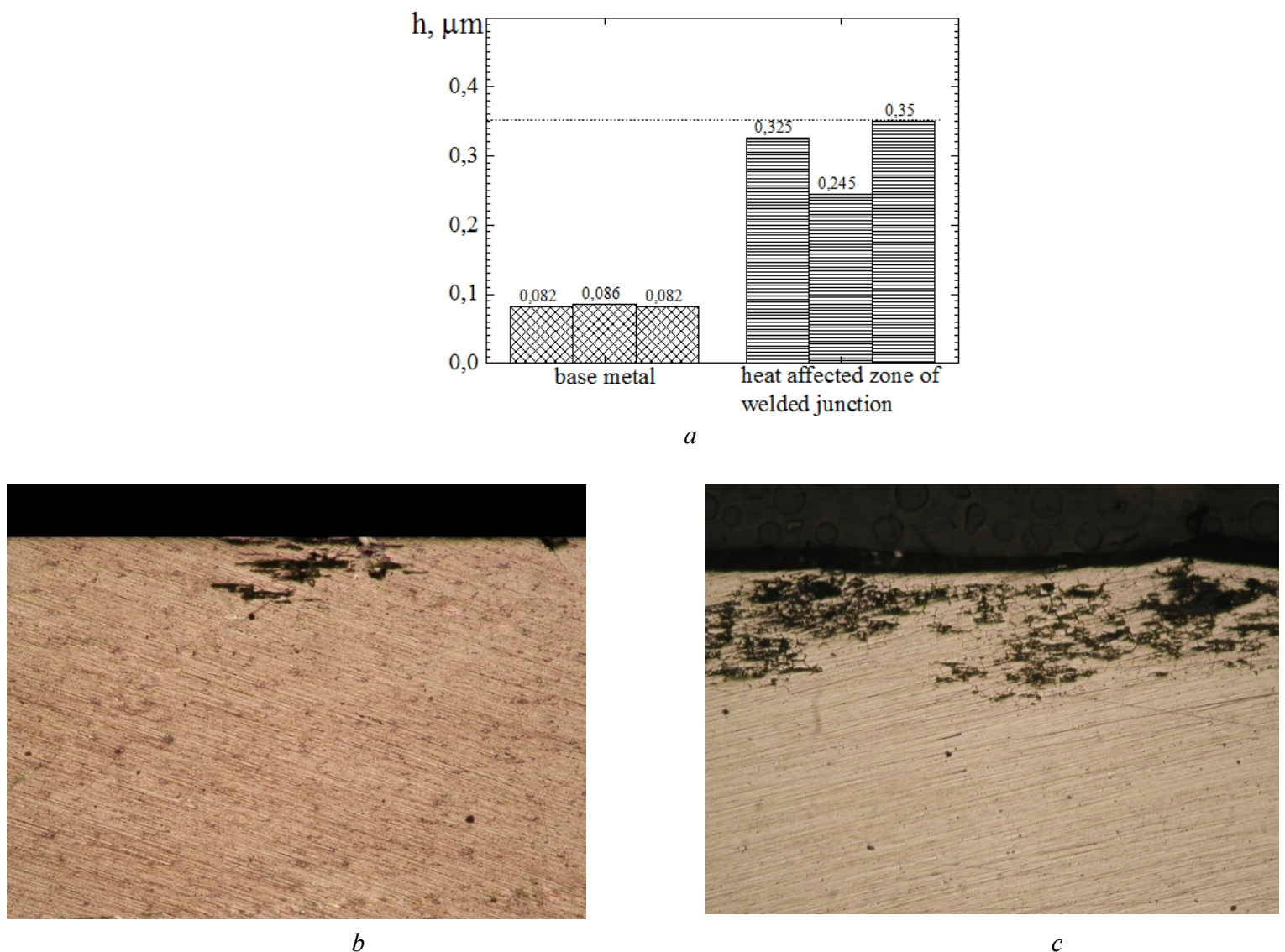

Fig. 6. The depth of the intergranular corrosion of the base metal of welded junction of aluminum alloy Al-Mg-Cu-Si $(a)$ and the photo of the base metal $(b)$ and the heat affected zone (c) after IGC resistance test
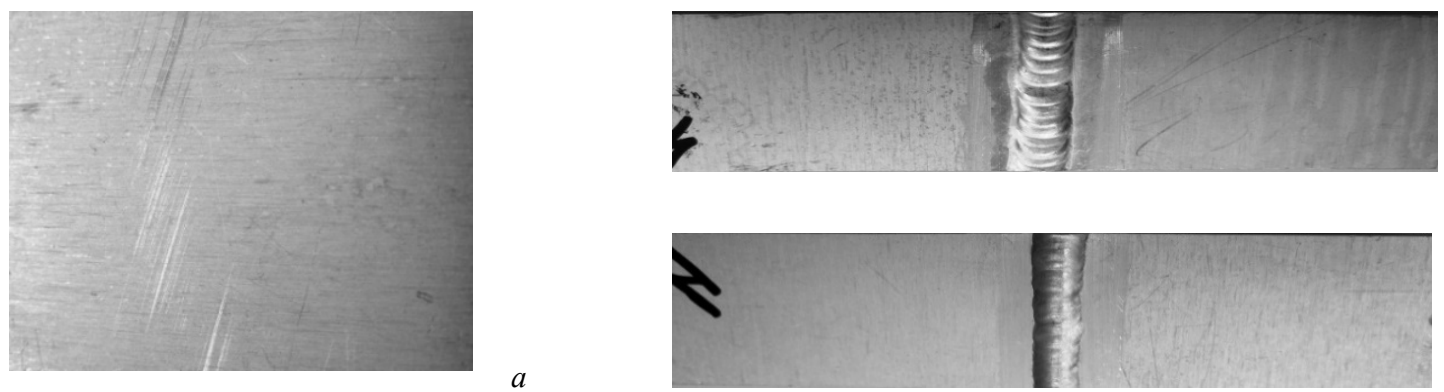

$b$
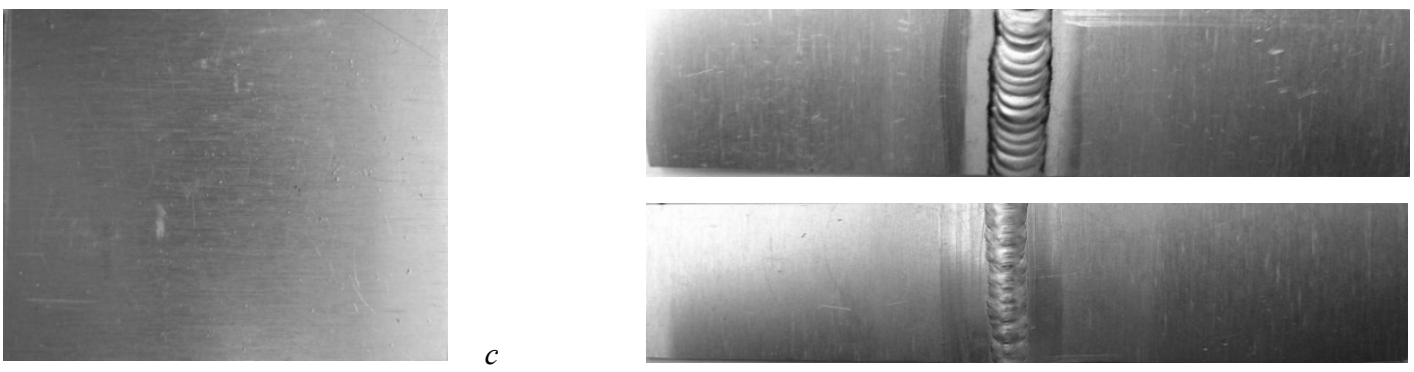

$d$

Fig. 7. Appearance of the surfaces of the base metal $(a, c)$ of aluminum alloy of Al-Mg -Si-Cu doping system samples and its welded junctions $(b, d)$ before $(a, b)$ and after $(c, d)$ accelerated tests for resistance against exfoliation corrosion 
thermal cycle of welding. Fig. 8 shows the appearance of the weld specimens, which were destroyed after 9 (Fig. 8b) and 49 hours (Fig. 8c) exposition in the corrosive environment. After the tests, a local darkening of the surface of the specimens was observed, the most intense was along the weld in the zone located at the distance of about 5-7 mm from the fusion line of the weld with the base metal. On the surface of the specimens, pittings were formed. Their density was also different, but the largest amount of pittings was situated at the distance of about 5-7 $\mathrm{mm}$ from the fusion line (Fig. 8b), and in some specimens - on the weld (Fig. 8c). Destruction occurs at the distance of about 5$7 \mathrm{~mm}$ from the fusion line, mainly in the zone of the largest concentration of pittings (Fig. $8 b, c$ ).
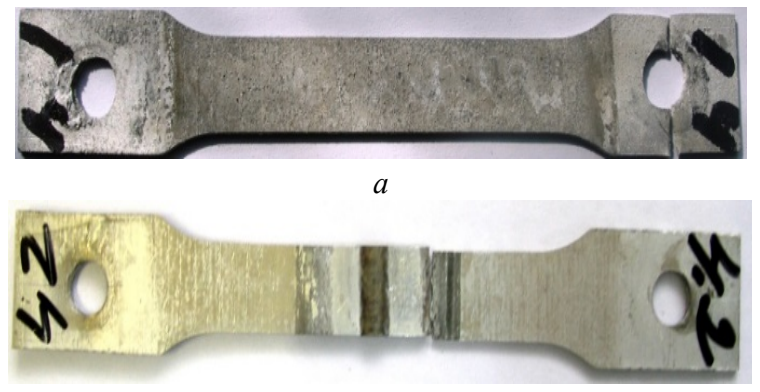

b

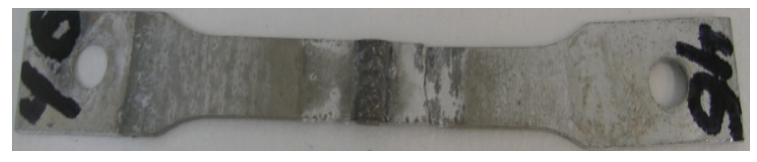

Fig. 8. Appearance of the sample surface of the base metal $(a)$ and the weld $(b, c)$ after corrosion and mechanical tests under a constant stress and immersion in $3 \% \mathrm{NaCl}$

Thus, according to the investigation results of resistance of aluminium alloy $\mathrm{Al}-\mathrm{Mg}-\mathrm{Si}-\mathrm{Cu}$ doping sistance of aluminium alloy $\mathrm{Al}-\mathrm{Mg}-\mathrm{Si}-\mathrm{Cu}$ doping system against local corrosion and corrosion under stress, it has been found that the destruction of the specimens of welded junction occurs at the distance near 5-7 mm from the fusion line, where the largest concentration of pittings occured. In this area, the intercgranular corrosion was observed, Fig. 6. It is appropriate to assume that intergranular destruction is initiated from the pittings, formed on the surface due to the violation of the integrity of the protective oxide film. Since the exfoliation corrosion resistance of the weld is satisfactory, the performance of the welded product as a whole, under conditions of a joint effect of corrosionaggressive medium and mechanical stress, will be determined by the stability of the heat-affected zone against the pitting and intergranular corrosion.

\section{Conclusion}

The results of metallographic studies have shown that melting of the metal during welding and its subsequent crystallization in the cooling process are accompanied by the separation of secondary phases and the coagulation of insoluble phases under the influence of the thermal cycle of welding. A significant number of the base alloying elements and impurities, which are part of the alloy, form a great number of metastable phases during the crystallization of welds. They are evenly distributed, but vary in size and shape. Decomposition of the supersaturated solid solution and the dissolution of the strengthening phases in the HAZ is occure. Their characteristic feature is the instability of decay within a single grain. The boundary areas are thus enriched with alloying elements, and the volume is depleted. Thin eutectic layers are formed along the boundaries of crystallites.

Electrochemical studies have shown that the potential of the weld and the heat-affected zone is more noble compared to the base metal. Taking into account a larger area of the base metal in the construction compared to the weld (the weld area does not exceed $10 \%$ of the area of the base metal), a satisfactory continuous corrosion resistance of the weld can be expected in general.

According to the results of the study of resistance against local corrosion and corrosion-mechanical research, it has been found that the destruction of the weld specimens occurs at the distance of 5-7 mm from the fusion line, where there is the largest concentration of pittings. It is assumed that intergranulal destruction is initiated from the pittings, formed on the surface due to the violation of the integrity of the protective oxide film. The weldability of the welded product as a whole under conditions of a joint effect of the corrosion-aggressive medium and mechanical stress will be determined by its resistance to pitting and intercrystalline corrosion.

Acknowledgements. The work was carried out within the framework of the departmental order program of the National Academy of Sciences of Ukraine by the E.O. Paton Electric Welding Institute in 2017-20219 (fundamental research works) "Establishment of regularities of corrosion resistance increasing of weld joints of construction aluminum alloys of different alloying systems received using welding technologies by melting and in a hard phase, for an air and marine transport" (State registration number 0117U001188). 


\title{
References
}

[1] M.A. Gureeva and O.Ye. Grushko, (2011). Scientific publications of VIAM staff 9. [Online]. Available: https://www.viam.ru/public/index.php?year=2011

[2] L.F Mondolfo, Structure and properties of aluminum alloys, Metallurgy, 1979.

[3] Z.N. Archakova, G.A. Balahovtsev and I.G. Basova, Structure and properties of semi-finished products from aluminum alloys, Metallurgy, 1984.

[4] J.E. Hatch, Aluminium. properties and physical metallurgy, red. J.E. Hatch, Metallurgy, 1989.

[5] M. Ando and Y. Suzuki, Proceedings of the 12th International Conference on Aluminium Alloys, 2010, pp. $1045-1050$.

[6] S. Wang et al., Proceedings of the 12th International Conference on Aluminium Alloys, 2010, pp. 2008-2011.

[7] Fam Hong Fu, "Improving the technology of heat treatment of wrought aluminum alloys of the Al-Mg-Si system based on the choice of cooling modes during hardening", Tes. of diss. candidate of Technical Sciences. 05.16.09. Moscow N.T. E Bauman 2016, 145 p.

[8] T. Kováŕík, J. Zrník, Proceedings of the 12th International Conference on Aluminium Alloys, Yokohama, 2010, pp. 1720-1725.

[9] K. Ichitani, K.Koyama, Proceedings of the 12th International Conference on Aluminium Alloys, Yokohama, 2010, pp. 363-370.

[10] A.E. Holder et al., Proceedings of the 12th International Conference on Aluminium Alloys, Yokohama, 2010, pp. 1475-1480.

[11] I. N. Fridlyander, et al., Scientific publications of VIAM staff 9, 2004. Available: https://www.viam.ru/public/files/2004/2004204044.pdf

[12] M.G. Kurs, et al., Aviation materials and technologies, no. 3, 2016, pp. 24-32.

[13] M. G. Kurs, Works of viam, no. 5, 2018, pp.101-109. https://doi.org/10.18577/2307-6046-2018-0-5-101-109

[14] Unified system of corrosion and ageing protection. Aluminium and aluminium alloys. Accelerated test methods for intercrystalline corrosion. GOST 9.021-74

[15] Unified system of corrosion and ageing protection. Alluminium alloys. Accelerated test method for exfoliation corrosion. GOST 9.904-82

[16] Unified system of corrosion and ageing protection. Alluminium and magnesium alloys. Accelerated test methods for corrosion crocking. GOST 9.919-74.

[17] Unifed system of corrosion and ageing protection. Aluminium, magnesium and alloys. Methods of accelerated corrosion test. GOST 9.913-90.

[18] Gaseous and liquid argon. Specifications. GOST 10157-2016.

[19] D.M. Rabkin, Metallurgy of welding by fusion of aluminum and its alloys, Nauk. Dumka, 1986.

[20] Welding - Arc-welded joints in aluminium and its alloys - Quality levels for imperfections. DSTU EN ISO 10042:2015.

[21] Unified system of corrosion and ageing protection. Metals, alloys, metallic and non-metallic coatings. Permissible and impermissible contacts with metals and non-metals. GOST 9.005-72.

\section{Корозійна тривкість зварного з'сднання алюмінісвого сплаву системи Al-Mg-Si-Cu}

\author{
Людмила Ниркова, Світлана Осадчук, Тетяна Лабур, Юлія Борисенко
}

Резюме. Наведено результати комплексних досліджень корозійної стійкості алюмінісвого сплаву системи легування $\mathrm{Al-Mg-}$ $\mathrm{Cu}$-Si. Методом металографії встановлено, щзо під впливом термічного ичиклу зварювання відбувається виділення вторинних фаз та коагуляція нерозчинних фаз. Основні легуючі елементи утворюють в процесі кристалізації швів метастабільні фази, які розтамовані рівномірно, але відрізняються розміром і формою. В зоні термічного впливу відбувається розпад пересиченого твердого розчину та розчинення зміцнюючих фаз, характерною ознакою яких є нестабільність розпаду в межах одного зерна, збагачення граничних ділянок легуючими елементами, збіднення об'єму. Що супроводжується утворенням тонких евтектичних прошарків вздовж границь кристалітів. Результатами електрохімічних досліджень встановлено, щьо потенціал зварного шва та зони термічного впливу є більш благородними порівняно з основним металом. Зважаючи на більшу площу основного металу в конструкиії порівняно із зварним швом (площа зварного шва становить не більше $10 \%$ від площі основного металу) в цілому можна очікувати задовільну стійкість зварного з'єднання проти суцільної корозії. Глибина міжкристалітної корозії зварного з'єднання сплаву системи Al-Mg-Cu-Si становить (0,245-0,350) цт, що більше ніж для основного металу - від 0,082 до 0,086 нт. Збільшення глибини руйнування границь зерен у зварному з'єднанні підтверджує факт розмічнення білямовної зони під час зварювання. Зварювання не погіршує стійкість зварних з'єднань проти розщаровуючої корозії порівняно з основним металом, яка оцінена балом 2-3 для основного металу та балом 1 для зварного шва та зони термічного виливу.

Стійкість зварного з'єднання в умовах сумісного впливу постійного навантаження та повного занурення у корозивне середовище знижується: час до руйнування основного металу становить від 67 до 88 годин, зварного з'єднання - від 1 до 49 годин. Оскільки стійкість проти розшаровуючої корозї зварного з'єднання задовільна, то працездатність зварного виробу в 
цілому в умовах сумісного впливу корозійно-агресивного середовища та механічного напруження буде визначатися стійкістю зони термічного впливу проти пітингової та міжкристалітної корозії.

Ключові слова: алюмінієвий сплав системи $\mathrm{Al}-\mathrm{Mg}-\mathrm{Si}-\mathrm{Cu}$; зварювання; стійкість проти корозї;; локальна корозія; корозійномеханічні випробування при постійному навантаженні.

\section{Коррозионная стойкость сварного соединения алюминиевого сплава системы Al-Mg-Si-Cu}

\section{Людмила Ныркова, Светлана Осадчук, Татьяна Лабур, Юлия Борисенко}

Резюме. Представлены результаты комплексных исследований коррозионной стойкости алюминиевого сплава системы легирования Al-Mg-Cu-Si. Методом металлографии установлено, что под влиянием термического ичикла сварки происходит выделение вторичных фаз и коагуляция нерастворимых фаз. Основные легируюшие элементы образуют в процессе кристаллизации швов метастабильные фазы, которые расположены равномерно, но отличаются размером и формой. В зоне термического влияния происходит распад пересыщенного твердого раствора и растворение упрочняющих фаз, характерныл признаком которых является нестабильность распада в пределах одного зерна, обогащчение пограничных участков легируюциими элементами, обеднение объема, что сопровождается образованием тонких эвтектических прослоек вдоль границ кристаллитов. Результатами электрохимических исследований установлено, что потенииал сварного шва и зонь термического влияния является более благородными по сравнению с основным металлом. Несмотря на больщую площадь основного металла в конструкции по сравнению со сварным швом (площчадь сварного шва составляет не более $10 \%$ от площчади основного металла) в иелом можно ожидать удовлетворительную стойкость сварного соединения в условиях равномерной коррозии. Глубина межкристаллитной коррозии сварного соединения сплава системы Al-Mg-Cu-Si cocmaвляет (0,245-0,350) мм, что больше, чем для основного металла-от 0,082 до 0,086 мм. Увеличение глубинь разрушения грании зерен в сварном соединении подтверждает факт разупрочнения околошовной зоны при сварке. Прочесс сварки не ухудшает стойкость сварньх соединений против расслачвающей коррозии по сравнению с основным металлом, которая оценена баллом 2-3 для основного металла и баллом 1 для сварного шва и зоны термического влияния. Стойкость сварного соединения в условиях совместного воздействия постоянной нагрузки и полного погружения в корозионно-активную среду снижается: время до разрушения основного металла составляет от 67 до 88 часов, сварного соединения - от 1 до 49 часов. Поскольку стойкость против расслаивающей коррозии сварного соединения удовлетворительная, то работоспособность сварного изделия в иелом в условиях совместного воздействия коррозионно-агрессивной среды и механической нагрузки будет определяться устойчивостью зоны термического влияния против питтинговой и межкристаллитной коррозии.

Ключевые слова: алюминиевый сплав системы Al-Mg-Si-Cu; сварка; коррозионная стойкость; локальная коррозия; коррозионно-механические испьтания при постоянной нагрузке. 